\title{
THE PLACE OF LUCERNE IN DRY-LAND FARMING
}

A. H. FLAY, Associate Professor of Farm Management and Rural Valuation Department, Lincoln College

Lucerne as a dry-land fodder plant is centuries old. It is used in most lands subject to dry summer conditions. Its deep rooting characteristic, its winter dormancy, and its rapid growth in high temperatures fit it for use in a wide range of climatic and soil conditions. It is readily eaten as hay or in the green state by all classes of stock. It will, however, not tolerate waterlogged or acid soils.

To establish the place of lucerne in dry-land farming it is necessary to examine a number of factors, the most important being the seasonal nature of its growth, the grazing management to which it must be subjected, and the effect a large area of lucerne can have on the overall carrying capacity of the farm. Finally, to demonstrate more clearly the place of luccrnc on a ploughable dry land farm, it is necessary to construct a farm unit with the maximum area in lucerne.

\section{Uses of Lucerne}

In New Zealand lucerne is used in all drier areas primarily for hay. It is being put to considerable grazing uses also.

As a hay producer it gives one or more cuts per year, even on the lightest of soils. Sometimes the first cut must be taken while spring showers still prevail, resulting in poor-quality hay. This can be avoided only by making silage. When cut at the correct stage of growth-just as the lower leaves begin to yellow a little-and properly cured lucerne hay is a high-quality feed which can be fed for a continuing period to any stock as the sole diet. The hay may be stored away from the weather for years with little deterioration.

As a grazing proposition in the beginning of spring, it provides some lambing green feed; it can be grazed throughout spring if required; and in summer it is extremely valuable for feeding newly weaned fattening lambs, for grazing hoggets, and for fattening annual draft ewes. Over the summer and autumn period it can provide feeding for flock ewes. In the winter-dormant state a lucerne stand can be used for a period as a "holding" paddock. It can be grazed hard at any time of the year for a short period only and it can be allowed to go completely unused for many weeks to be grazed in the full flowering and/or semi-wilted state. 
In the semi-wilted but not woody state it is at its best as a fattening feed. It can be left ungrazed, hayed, or allowed to Bower and seed in a bountiful season and if the seed crop should be a failure, no harm is done. Even a massive crop can seed and lie down with seemingly smothering effects without injury to the stand. It can be grazed when $2 \mathrm{in}$. high or at $12 \mathrm{in}$. or more. It responds rapidly to summer rains and normally grows longer into summer than the usual pastures.

Lucerne has several unfavourable features. It is not tolerant of waterlogged, acid soils. When grazed in the early luscious state of growth, it does not appear to be very palatable and sheep sometimes do not thrive and lambs do not fatten on a pure diet of such feed, especially in wet weather. It does not grow at low temperatures to give a green "bite" over winter as does ryegrass. Late summer or autumn growth will not carry forward as autumnsaved pasture for winter or spring grazing, as it suffers from frost burn.

\section{Production from Lucerne and its Seasonal Growth}

Lucerne on dry land produces annually about one-third more feed than the usual pastures (I ). Two-thirds of this feed, however, is normally grown in the three months of spring ( 1). Thus while lucerne has the advantage of higher production than the usual pastures, it presents the problem of conservation and the provision of feeds at other times. Also in one season the production may be $7,000 \mathrm{lb}$ of dry matter per acre and in another 3,740 $\mathrm{lb}$ (1).

Pastures, too, on dry land present a similar year-to-year range at a lower level, but lucerne does give a relatively higher production than pastures in summer and autumn. There could in some seasons be an excellent growth in December and again in February or in April extending into May as occurred in 1962. These variations from season to season can result in lucerne pastures carrying up to $5 \frac{1}{2}$ to 6 ewes and their lambs per acre in one spring and in the next only $3 \frac{1}{2}$ to 4 ewes and their lambs. Under these circumstances in some seasons little or no hay (or silage) can be made while in another it is possible to save hay from more than one-half of the total lucerne area. This feature presents a management problem involving the build up of hay reserves before increasing stock to the maximum.

\section{The Lucerne Seed Mixture}

Lucerne is usually sown alone when required primarily for hay, but nowadays the objective is usually hay and grazing. Under these circumstances it is usual to sow a somewhat lower seeding rate of lucerne together with sub clover and/or white clover plus 
a light seeding of cocksfoot, phalaris, prairie grass, and/or perennial ryegrass. A dual-purpose pasture is obtained which in low-production seasons would be used perhaps entirely for grazing and in bountiful seasons some of the areas are used for hay production. For maximum yields of a high quality hay the stand should be free of grasses. Later as weed invasion develops the pure lucerne stand may, if deemed advisable, be oversown with clovers or grasses.

\section{The Pattern of Farming in Dry Land Areas}

Over the year on the dry-land areas there has been developed a pattern of farming that has been proved most suitable. This pattern consists of fat lamb production associated with the joint products of mutton and wool. There has been little departure from this over the past 50 or 60 years, except perhaps to produce a few fat cattle or on the better soils some cash crops.

In fat lamb farming an adequate and economical feed supply throughout the year is essential. It should be produced with a minimum input of labour. Towards this end permanent highproducing sub clover and other pastures have been developed with the aid of liming and superphosphate topdressing. These pastures, assisted by the use of DDT for grass grub and porina control, have promoted increased carrying capacities. These pastures alone, however, are not sufficient to give maximum carrying capacity. In fact substantial quantities of hay (and silage) are essential for drought and winter periods. It can be produced reliably and economically in dry-land areas mainly from luccrne and clover pastures. Hence most occupiers have a small lucerne hay area. Rape and/or a rape mixture is usually grown for summer and autumn fattening or for winter feed. Crops of green feed oats (wheat or ryecorn) or Italian ryegrass may provide autumn, winter, and lambing green feed. Root crops sown alone provide winter feed and sown with Italian ryegrass may provide winter and lambing green feed; autumn-saved pastures may also provide some winter and lambing green feed. A combination of several types of supplementary crops is the most acceptable and appears to provide economically out-of-season feeds. When these arc supplemented by substantial reserves of (shed) covered hay a fully reliable out-of-season feed supply is on hand.

\section{Lucerne as the Feed Supply over the Year}

In dry-land districts lucerne normally produces two-thirds of its total annual production in the three spring months. This fits in well with fat lamb production, coinciding remarkably with the nutrition requirements of the milking ewe and fattening lamb. For 
a continuing supply of feed throughout the year lucerne is the one fodder plant that comes nearest to meeting all requirements. With an adequate supply or hay (and silage) conserved from surplus spring growth, and where lambing is not especially early in relation to normal spring growth, lucerne can supply the total year's feed supply.

Poorer quality hay can be fed to flock ewes after weaning. In fact any quality hay may be fed in a drought summer, but reasonable quality is desired for autumn and winter and a good quality approaching and during lambing.

On practical and economic grounds, however, it is more satisfactory to produce the accepted supplementary crops for lambing green feed and sometimes a rape mixture for lambing fattening. These crops, although involving extra costs of production, give a spread to seasonal work compared with a short intensive haymaking period. Further their total production is as high or higher per acre than that of lucerne (1), their feeding quality for their special use is better than lucerne hay, and they can be fed in situ, thus saving the labour of feeding out. Also there is less anxiety and less rush of work with cultivation than with hay (or silage) making. Further most fodder crops now in use fit in well as preparatory crops for lucerne renewal. Their production, however, is just as variable from season to season as lucerne's and thus hay (and silage) remains a necessity supplement.

Normally it is lucerne that provides the most reliable and economic source of hay in dry-land areas. Further the supply of hay is known early in the season. While with autumn-sown crops there is always some winter and lambing feed, the quantity is not known until winter; but also sometimes a first cut of lucerne hay is completely ruined by bad weather and there may not be a second.

While supplementary fodder crops are normally desired tendency has usually been to keep their area at a minimum and to use hay as part of the out-of-season feed and as a "buffer" feed.

Lucerne may be used as lambing green feed, but this must be compatable with normal hay requirements from first cuts, especially on areas normally. producing only one hay cut annually.

To help over the summer dry periods standing lucerne can be carried forward. Here lucerne supplements rape as a lamb fattening feed. The summer feed shortage for adult sheep can be cushioned to a limited extent by the use of run-out lucerne and other suitable areas for "holding" paddocks on which weaned ewcs 
are held at high concentration for a few weeks and high conditioned ewes are held for longer periods, using some body fat as drought feed. This practice avoids damage to highly productive and younger areas of lucerne or pasture. Rationing of autumn growth to ewes is an effective method of securing efficient usage without damage to the stand. It has the advantage that an area is relatively quickly defoliated. Its use is limited during tupping should the diet be purely lucerne on account of some lowering of lambing percentage (2).

When required, hay is also fed in the "holding" paddock.

Winter food consists of the usual pasture (or lucerne) pickings from "holding" paddocks, the rationing of roots and greenfeed, and the feeding of hay.

Fat Lamb Production, Grazing M anagement of Lucerne, and Life of Stand

Maximum fat lamb production is the objective on the dry-land farm and this, especially, off the mothers, Breeds of ewes and rams are important, but feed quality, quantity, and grazing management are the determining factors. Lambs thrive best when left undisturbed. So important is this that the farm manager adopts the set stocking or semi-set stocking method of grazing manage- " ment. This means that for set stocking a given mob of ewes and their lambs are tailed on to a field and left there until drafted as "fats" or weaned. Sometimes a few ewes and lambs may be added or a few taken out. When semi-set stocking is the method the size of mobs is such that they are shifted on to similar or better feed only at lengthy intervals, perhaps two or three times during the fattening period of eight to 10 weeks from tailing to drafting.

For lamb fattening on mothers in spring, lamb fattening after weaning in summer and autumn, and ewe hogget grazing in summer and autumn set stocking and semi-set stocking are the most satisfactory methods for maximum stock shift. These methods are invariably practised. Under such grazing conditions lucerne slowly deteriorates, and weed invasion steadily takes place.

The ideal grazing for lucerne is quick defoliation with a large mob and then a long spell until the growth again is 9 to $12 \mathrm{in}$. or more high and ready for the next quick defoliation. Only under haying conditions, or with ration grazing or mob stocking in summer or autumn, can this take place. The wisdom of complete defoliation from the lucerne view point in drought times is very much open to question.

To assist lucerne to become well established new stands should be hayed. The older stands with a content of sub clover, white clover, and a small content of other grasses are good lamb fatten- 
ing feed, but when cocksfoot and inferior grasses become dominant the fattening quality deteriorates. However, in these pastures with a low stocking rate, so that lucerne and clovers provide the diet, good fattening is obtained. This low stocking rate, while essential for fat lamb production, does mean, of course, that the desirable species are kept short while the undesirable and less palatable get out of hand. The continued grazing of the lucerne and the neglect of grasses (weed or otherwise) assist further deterioration of the lucerne.

The frequency of haying, the varying severity of different grazing methods, and the rate of weed ingress are three important factors that determine the life of lucerne stands. For the average soil with normal topdressing and appropriate liming the life of a lucerne stand of Marlborough variety ranges from six years to 10 or 12 years, a fair average being eight years. For the creeping variety the life appears to be two or three years longer. At Ashley Dene some areas of Marlborough have lasted 12 years and some of creeping 15 years.

\section{Lucerne Stands as Holding Paddocks}

Many dry-land farming areas are associated with hill country. These hills are frequently used, especially in drought times, for off-season grazing and heavy stocking' when spelling highly productive swards and when rationing special fodder crops and/or feeding hay. On ploughable farm lands such "holding" paddocks are normally those next due for cultivation for supplementary crops. With fodder crops normally kept at a minimum the area next to be ploughed out of grass is usually insufficient to meet the "holding" area requirements in summer, autumn, and winter. Sometimes highly productive lucerne or pasture swards have to be used at 20 ewes or more per acre for several months and should this occur, the desirable species are usually severely weakened and may be destroyed. Sub clover, however, by virtue of its re-seeding habit, does survive this treatment in drought summers. Thus to make up the deficiency in "holding" areas some farmers retain a number of old, dominantly sub clover pastures for this purpose.

In maintaining the maximum area of lucerne in a highly productive state for as long as possible and also keeping renewal costs at a minimum, an area of old pasture that can stand abuse as a "holding" area in times of need is invaluable. On the $87 \%$ acre Ashley Dene farm there are all told 160 acres of such pasture over 15 years old-one 26-acre paddock is 22 years old. On the basis of sheep-grazing days (holding days) these areas are the most productive on the farm. In spring they still carry from 3 to 5 ewes and lambs per acre. 
In winter lucerne areas are frequently used as "holding" paddocks for hay feeding and for rationing of fodder crops. The heavy stocking quickly grazes the small lucerne shoots to ground level. They are kept bare for the duration of the use as a "holding" area. When this condition is of relatively short duration, say three or four weeks, the lucerne appears to suffer little. The early spring growth that would have occurred is delayed somewhat, but the built-up fertility promotes greater production later. Development or invasion of weeds and weed grasses, however, appears to be hastened. This can be delayed, of course, by the avoidance. of feeding on the area hay containing weed and grass seeds. The practice does allow pastures to be spelled over winter and thereby to provide a greater volume of lambing green feed.

\section{Some Comparisons and Contrasts between Special Fodder Crops and Lucerne}

In dry-land farming, fodder crops are sown to provide large volumes of feed for special periods of natural shortage. They must be used in the current season and cannot be carried forward as can lucerne hay.

Production costs of supplementary crops, other than that for cultivation, are relatively low-about $\mathfrak{E l}$ per acre or less for seeds. The ease of feeding in situ is a favourable factor. Also for every acre of renovated sub clover and temporary ryegrass there is practically a guarantee that three or four fat lambs per acre will be drafted (at light weights) off the mothers early at eight or 10 weeks after tailing. (This pasture is a first-class lamb fattening feed.)

Lucerne at 10 or $12 \mathrm{lb}$ of seed per acre for a pure stand or at half this rate plus clovers and grasses may well cost up to $£ 6$ or more per acre. A soil $\mathrm{pH}$ of over 6.0 is almost essential for lucerne, but sub-clover and temporary ryegrasses will thrive at a lower lime status.

On dry land lucerne is usually sown early in spring, when a moist seedbed can be guarantced. It gives little or no feed over the dry summer, is usually hayed the next season, and is fed in subsequent winters-a lag of over two years between expenditure and returns. This lag influences farmers to grow fodder crops which frequently give a higher total feed per acre for the year than lucerne. These. crops can be rationed to feed 12 to 25 ewes per acre for thrce winter months (1), or to feed up to 20 ewes or ewes and lambs per acre for four to five weeks in early spring. This factor together with those mentioned earlier influences farmers to cultivate for an adequate though minimum area of fodder crops, using lucerne hay as a "buffer". 


\section{Large Areas of Lucerne give High Carrying Capacities}

The advantages of lucerne on dry-land outweigh by far the shortcomings and difficulties of its management. Because of this progressive and leading farmers continue to develop a high proportion of their properties into this plant (3). While a recent survey of dry-land (light soils) in Malvern County near Christchurch (4) covering the period 1954-1959 revealed that the average farm there of 853 acres was growing 52 acres of lucerne and carrying 1.8 ewes per acre, one farmer, D. Watson, in the area at Sandy Knolls (5), on 444 acres, with 157 acres of Lucerne (a third of the farm) is in 1962 carrying profitably 3.5 ewes per acre. Ashley Dene nearby has carried for the past four years 3.4 and 3.5 ewe equivalents per acre on its 878 acres with an average of 336 acres of lucerne (two-fifths of the farm). E. C. Topp in 1955 on his 1,125 acres had 650 acres of lucerne (half of the farm) and was then carrying 2.6 ewe equivalents per acre (6). (Mr Topp's ewes clip just over $12 \mathrm{lb}$ of wool and give an average lambing of over 130 per cent, and thus it appears he is lightly stocked.)

\section{The (Possible?) Maximum Area of Lucerne on the Dry-land Farm}

The fat lamb farmer on dry-land for maximum production requires :

1. A maximum area in topdressed lucerne and lucerne-sub clover-grass pastures.

2. A minimum area of "holding" pastures of dominant sub clover, etc. at low altitudes and of other clovers at high altitudes.

3. An adequate area of green feed at lambing; of roots, etc. for winter; and of lamb fattening feed in summer.

4. A maximum number of lambs fat off the mothers and a maximum area of grazing for ewes and lambs in spring compatible with a sufficient supply of hay for winter and drought feeding over the average of years.

5. A sufficient area for lucerne renewal annually.

A maximum draft of fat lambs off the mothers requires an adequate feed supply at all times and especially of fattening quality in spring and early summer. At the same time an adequate supply of good hay must be conserved. These objectives are aided by a minimum area under the plough in spring for new lucerne and for supplementary lamb-fattening feed. Thus the area in rape or rape mixture should be at a minimum (or nil) and semi-wilted lucerne adequate for fattening weaned lambs. The winter root (autumn-sown turnips) area can be cultivated out of grazing land from December to sowing in February and likewise the green feed area, thus leaving the maximum area for grazing in spring. 
From a study of performances at Ashley Dene and on other farms a land-use programme with two-thirds of the farm in lucerne can be suggested. This possible maximum fits in with and facilitates the above five requirements. For a 900-acre property all of which is ploughable and carrying 3,200 ewe equivalents (2,600 ewes, 800 ewe hoggets, and 100 dry sheep) the position is as follows:

\section{Land Use-900 acres Dry Land Farm}

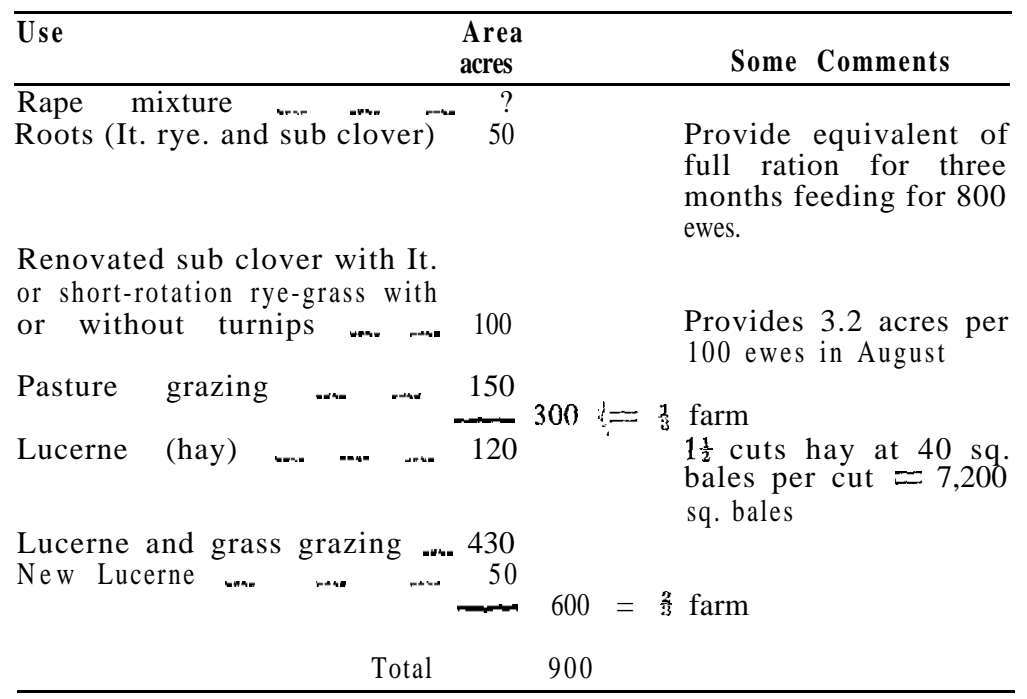

As already mentioned spring and early summer production is very variable but on average the position may be represented as follows:

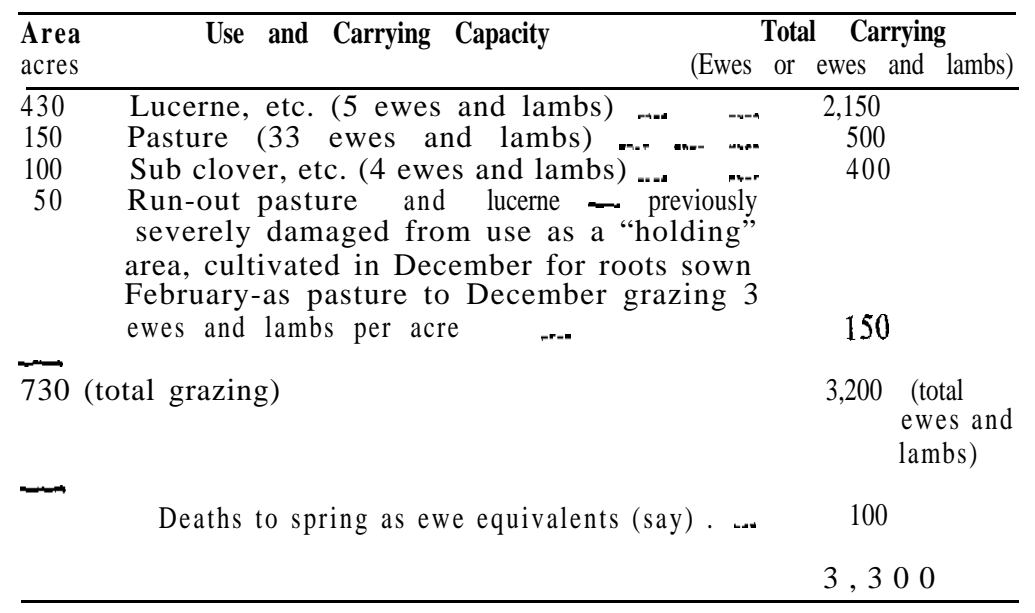


Winter feed on average may be accounted for as follows:

\begin{tabular}{llcccc}
\hline $\begin{array}{l}\text { Area } \\
\text { acres }\end{array}$ & Land Use and Hay & Ewe & Equivalents & Fed \\
\hline 5 & Roots @ 16 ewes per acre for 3 months & 8 & 0 & 0 \\
350 & Pasture pickings @ 1 ewe per acre over winter & 350 & \\
$-\quad$ Hay 6,150 sq. bales @ 3 bales per ewe & $\ldots$ & 2,050 & \\
& & Total & 3,200 & \\
& & & & & \\
Surplus for drought use (annual average) & $\ldots$ & $\ldots$ & 1,050 & bales \\
\hline
\end{tabular}

Hay supplies should be built up to two years' normal requirements before the above full carrying is attempted unless of course the farmer is prepared to carry out annual stock adjustments in accordance with current feed supplies. It must be recognised that the above represents the "average" season, which never occurs; one year there is a surplus and the next a shortage. At Ashley Dene in the 1960-61 season 12,744 square bales of hay were harvested from 170 acres (with 95 acres giving a second cut and 27 acres a third cut), while in the next season only 300 square bales were taken from 20 acres. Sheep numbers were approximately the same.

With high production lucerne pastures, "holding" paddocks for weaned ewes are an essential feature of summer feed and pasture management. From late November or early December 50 acres going to turnips in February are used as a "holding" area. Almost immediately in December 100 acres of dying sub clover and Italian or short-rotation ryegrass become available. This area is eaten bare very quickly. Both areas are cultivated, usually before Christmas. At this time the ewes are used to clean up roughage on older or any lucerne areas requiring this treatment. In drought seasons there is insufficient roughage and at these times hay of one sort or another must be fed in suitable "holding" areas. Such areas are old sub clover pastures of sufficient size to hold the breeding flock at up to 20 ewes per acre or more for several weeks and in extreme droughts for one or more months. Up to 150 acres may be used without damaging the lucerne pastures, which in this example total 600 acres (550 acres established and 50 acres new). Two-thirds of the farm is in lucerne.

It could be suggested that under most circumstances the effective area of lucerne (allowing for drought damage) where there are no suitable "holding" pastures, is not likely to exceed greatly two-thirds of the farm. If this proportion were exceeded, a portion would have to be creeping lucerne,. A sufficiently large annual sowing of new lucerne could raise the effective area to 
perhaps three-quarters of the farm, but a portion-creeping or otherwise-would have to be damaged prematurely each drought summer. This would seem to be an unnecessary waste and thus it appears that two-thirds of the farm in lucerne is likely to be the maximum.

Resowing of lucerne is, up to a point, a function of the area in root or rape crop.

\section{Summary and Conclusion}

Lucerne is an extremely valuable fodder plant in dry-land areas both for hay and grazing. It lasts for 6 to 12 years and gives 30 to 40 per cent higher production in these areas than other permanent pastures. Its annual feed production per acre is only exceeded by some special annually sown fodder crops.

It is best supplemented by areas of fodder crops; but properly saved good-quality lucerne hay (and silage) can be stored for many years for feeding for periods as the sole diet of stock.

Its establishment is expensive and the return from this expenditure is subject to a significant lag, which acts as a deterrent to the greater use of lucerne. Those farms with large areas in lucerne have significantly high and profitable carrying capacities.

The maximum area of effective lucerne that might be usefully maintained on the average ploughable dry-land farm is not likely to exceed two-thirds. This means that on most farms in dry-land areas there still remains a considerable potential for increased production.

\section{References}

$1 \mathrm{~J}$. W. Calder and C. E. Iversen: Annual. reports of research work on pastures at Ashley Dene, 1955 to 1959 incl.

J. W. Calder and C. E. Iversen: "Light Land Pastures", Proc. N.Z. Grassland Conference, 1956

J. W. Calder-"Pasture Research at Ashley Dene", Proc. Lincoln College Farmers' Conference, 1956.

$\because$ I. E. Coop and V. K. Clark: "The Reproductive Performance of Ewes Mated on Lucerne", N.Z. J. Agr. Research, Vol. 3, No. 1960.

3 A. H. Flay--"Potential Production of Light Plains Land", Proc. Lincoln College Farmers' Conference, 1956.

$\uparrow$ Unpublished production and land use records of the average of 39 light-land farms in Malvern County.

5 David Watson: "Light Land Development", Proc. Lincoln College Farmers' Conference, 1962.

6 J. W. Calder, C. E. Tversen, and a group of South Island farmers, Proc. Lincoln College Farmers' Conference, 1955. 


\section{DISCUSSION}

Q. Can you think of any other way of providing feed other than growing root crops on dry land? While lucerne is easy to grow on dry land root crops are not.

A. While I agree that root crops are difficult to grow on light land, this is not the case on the second round after lucerne when you sow on the first of February short rotation ryegrass or Italian rye with renovated sub clover, and throw in $6 \mathrm{oz}$ of York globe turnip to get a quantity of winter feed. The essential thing is that you must have a reserve of lucerne hay or silage, you can then feed $\frac{3}{4}$ of the ration as lucerne, and 1/10 of supplementary green feed or partial root crop.

Q. Is there any evidence that the feeding quality of lucerne hay increases on storage?

A. I do not know. All I know is that if lucerne hay heats up a little because of moisture it is more palatable than when it goes in perfectly dry.

Q. Are you prepared to elaborate on the use of prairie grass in conjunction with lucerne in dry land farming?

A. I have not been particularly impressed with one or two instances where I have seen it used but I' shall leave the question to Dr Langer and other experts.

Comment (I. L. Elliott): The point that has been raised is that prairie grass is well recognised as a winter grower and you have this considerably long dormant period in lucerne growing to fill in and the use of prairie grass might overcome this difficulty.

Comment (Mr O'Reilly): In Australia we do not favour the growing of subterranean clover- with lucerne and other grasses. If you do this, there is a tendency to overgraze your lucerne stands, and there is no quicker way of forcing lucerne out than by doing this. When you get a really good stand of subterranean clover the young seedlings develop so rapidly that they crowd the lucerne out of the stand.

A. This clover does not grow a great deal in winter on our dry land areas as it is too cold. The farmer wants a lot of fat lambs off the mothers quickly, and we have found that the sub-clover/lucerne combination is one of the best fattening feeds and is second only to a sub-clover/ temporary ryegrass combination. For this reason you can afford to have grazing, and sub-clover pushing lucerne out over an 8 year period, rather than let the stand go on for 12 years.

Comment (R. Moody): There are good stands of lucerne and prairie grass in the Galatea area.

Comment (Chairman): I imagine these would be on dairy farms, and not on sheep farms, and secondly. that the Galatea region though droughty has an annual rainfall of $50 \mathrm{in}$. (this year it must be 70 to 80 in.). These two factors would tend to take it out of the particular environment Professor Flay was talking about. 